\title{
Ferralsol Porosity and Density After Mechanical Scarification and Crop Rotation Systems
}

\author{
Monica C. Sustakowski ${ }^{1}$, Edleusa P. Seidel ${ }^{1}$, Renata F. Barabasz ${ }^{1}$, Rayssa H. da Silva ${ }^{1}$, Willian dos Reis ${ }^{1}$, \\ Juliano Zimmermann ${ }^{1} \&$ Maria do C. Lana ${ }^{1}$ \\ ${ }^{1}$ Center of Agrarian Science, State University of Western Paraná, Paraná, Brazil \\ Correspondence: Monica C. Sustakowski, Center of Agrarian Science, State University of Western Paraná, \\ Paraná, 85960-000, Brazil. Tel: 55-45-98803-8310. E-mail: monica_sustakowski@hotmail.com
}

Received: August 3, 2020

doi:10.5539/jas.v12n10p316
Accepted: September 5, $2020 \quad$ Online Published: September 15, 2020

URL: https://doi.org/10.5539/jas.v12n10p316

\begin{abstract}
With intensive cultivation and the lack of crop rotation, the no-tillage system has been showing compacted areas. For its reduction, mechanical scarification and crop rotation has been recommended. Thus, the present study aimed to evaluate in a no-tillage system the effect of mechanical scarification and crop rotation systems on soil porosity and density after 18 months. The experimental design used was randomized blocks in a split-plot scheme, with four replications. The main plots consisted of maintaining the no-tillage system and minimal soil preparation with a chisel, carried out before the cultivation of cover plants. The subplots were composed of different plant species grown in winter: wheat, consortium of forage pea + black oat and consortium of black oat + forage turnip. Both were succeeded by cultivation of soy and lupin. Macroporosity, microporosity, total porosity and bulk density were evaluated. After 18 months, the scarified soil showed a higher bulk density (0.10-0.15 m layer) when compared to the no-tillage system, demonstrating that this isolated decompression alternative does not improve the physical properties of the soil. The area in succession to oat + turnip/soybean/lupin showed lower bulk density.
\end{abstract}

Keywords: compaction, no-tillage system, cover plants, physical quality

\section{Introduction}

With the modernization of techniques used for the agriculture success, the no-tillage system has become an important instrument for the improvement, maintenance and recovery of adequate physical characteristics and productive capacity of managed soils.

However, over the years of adoption of this system, there are still frustrations in agricultural crops, which, according to Drescher, Eltz, Denardin, and Faganello (2011), is due to several factors, among them: excessive traffic, as well as the lack of crop rotation with production of residues in quantity, quality and frequency lower than the soils biological demand.

This tends to alter the original soil structure, by fractioning the aggregates into smaller units, resulting in the approximation between the particles and a reduction in the size of the pores (Drescher et al., 2011).

Thus, there is a reduction in the macropores volume, responsible for the aeration and drainage of soil, while there is an increase in the micropores volume, responsible for water retention and soil density (Panachuki, Bertol, Alves Sobrinho, Oliveira, \& Rodrigues, 2011). As a result, soil compaction problems are frequent.

Compaction is considered one of the main problems of soil degradation and impairment of agricultural production, as it causes a reduction in the water availability to plants and excessive mechanical resistance of soil to penetration in conditions of water deficit, while causing deficiency of aeration of soil, changing the nutrients dynamic and causing physiological problems in plants when in rainy conditions or excessive irrigation (Klein, 2010).

Thus, when soil compaction becomes limiting for agricultural production, it is necessary to adopt mitigation measures in order to reduce soil density, increasing porosity and, simultaneously, breaking compacted layers. Among these measures, the most used practice has been mechanical scarification, with use of stem chisels. 
However, the efficiency of scarification has been controversial, since it has a temporary effect on soil and a small residual effect of the conditions created, which ends up making the soil susceptible to new compaction processes (Girardello et al., 2014; Rosa et al., 2018).

In view of this, it turns out the importance of developing and using practices that aim to combat soil degradation, recover its quality and maintain the benefits generated by the adoption of no-tillage system (Silveira Junior, Silva, Figueiredo, Tormena, \& Giarola, 2012).

Based on this, crop rotation with species that have a deep and vigorous root system emerged as an alternative to the mechanical method of scarification, due to its ability to grow in soils that have high resistance to penetration, improving its structure and benefiting plants growth, thus constituting an effective way of soil conservation (Rosa et al., 2018).

One of the main cover crops in the Southern Region of Brazil is the black oat (Avena strigosa S.), a species cultivated in large extent as a winter cover plant and widely cultivated in intercropping with forage peas, forage turnip and vetch. Its use as a cover plant is due to its rusticity, tillering capacity, quickly formation of soil cover and high production of phytomass. It also has drought tolerance, due to the well developed root system, efficiency in nutrient recycling and high carbon/nitrogen ratio $(>30)$ which results in a low rate of waste decomposition (Bortolini, Silva, \& Argenta, 2000; Calegari, 2001).

Forage turnip is an important species used as a ground cover plant. Due to its deep and pivoting root system, it is indicated to decompress and improve the soil structure, providing increases in soil porosity, favoring water infiltration and the development of roots of subsequent plants. In addition, due to its low carbon/nitrogen ratio, the decomposition of its residues occurs quickly, so the use combined with slower decomposition species is a good option to keep the soil protected for a longer time (Hernani, Endris, Pitol, \& Salton, 1995).

The plants of the Fabaceae family, such as forage peas, also have a low carbon/nitrogen ratio, providing a quickly availability of nutrients to the crop in succession and greater stabilization of soil aggregates (Doneda et al., 2012).

The lupine (Lupinus albus) has been widely used in Brazil as a cover plant against soil erosion, due to its high production of dry matter, falling into the class of plants intended for conservation management systems, however, due to its high protein content, is an oilseed widely used in the feeding of ruminants (Cremonez et al., 2013).

However, the efficiency of the biological method also depends on the initial state of soil compaction, because when soil has very high levels of density and resistance to penetration, even the species indicated for this purpose have limited root development (Cubilla, Reinert, Aita, \& Reichert, 2002).

Based on this, the hypothesis adopted is that the mechanical scarification of soil has an ephemeral effect on the improvement of its physical characteristics, while cover crops provide a more lasting effect on soil. The objective of this work was to evaluate in a no-tillage system the effect of mechanical scarification and crop rotation systems on soil porosity and density after 18 months.

\section{Method}

\subsection{Location, Climate and Soil of the Experimental Area}

The experiment was conducted in Entre Rios do Oeste, Paraná, southern Brazil; at geographic coordinates of latitude $24^{\circ} 40^{\prime} 54^{\prime \prime} \mathrm{S}$, longitude $54^{\circ} 17^{\prime} 3^{\prime \prime} \mathrm{W}$ and altitude $251 \mathrm{~m}$ in relation to sea level.

The region's climate is classified as Cfa, subtropical humid mesothermal, according to the Köppen climate classification, with hot summers with a tendency to concentrate rainfall (average temperature above $22{ }^{\circ} \mathrm{C}$ ), winters with unusual frosts (average temperature below $18{ }^{\circ} \mathrm{C}$ ), without defined season and average annual precipitation around 1600 to $1800 \mathrm{~mm}$ (Caviglione, Kiihl, Caramori, \& Oliveira, 2000).

The area has been cultivated for 14 years in minimum cultivation with the succession of soybean crops in summer and corn in fall/winter, that is, no crop rotations were carried out. In the last two years, there were no organic fertilizers in the area and the fertilization used was from commercial formulations $\mathrm{N}^{-} \mathrm{P}_{2} \mathrm{O}_{5}-\mathrm{K}_{2} \mathrm{O}$, with an average dose of $300 \mathrm{~kg} \mathrm{ha}^{-1}$. The average productivity in the last two years of soybeans was $3000 \mathrm{~kg} \mathrm{ha}^{-1}$ and maize of $4958 \mathrm{~kg} \mathrm{ha}^{-1}$.

Before the implementation of the experiment, soil samplings were performed in the $0.0-0.20 \mathrm{~m}$ layer to determine the chemical characteristics and soil granulometric composition, and in the $0.0-0.5 \mathrm{~m}, 0.05-0.10 \mathrm{~m}$ and $0.10-0.15 \mathrm{~m}$ layers to determine the initial physical characteristics. 
The soil presented the following chemical characteristics: $\mathrm{pH} \mathrm{CaCl} 24.71$, O.M. $19.57 \mathrm{~g} \mathrm{dm}^{-3}, \mathrm{Al}^{3+} 0.25 \mathrm{cmol}_{\mathrm{c}}$ $\mathrm{dm}^{-3}, \mathrm{P} 10.07 \mathrm{mg} \mathrm{dm}{ }^{-3}, \mathrm{~K}^{+} 0.89 \mathrm{cmol}_{\mathrm{c}} \mathrm{dm}^{-3}, \mathrm{Ca}^{2+} 3.64 \mathrm{cmol}_{\mathrm{c}} \mathrm{dm}^{-3}, \mathrm{Mg}^{2+} 0.78 \mathrm{cmol}_{\mathrm{c}} \mathrm{dm}^{-3}$ and $\mathrm{V} \%$ 55.85. No liming was carried out before the experiment was implanted, but it was scheduled to be carried out for the cultivations after the end of this experiment.

To determine the granulometric composition of soil, the Bouyoucos densimeter method was used, according to the methodology proposed by Donagemma et al. (2017), being found the values of $544 \mathrm{~g} \mathrm{~kg}^{-1}$ of clay, $382 \mathrm{~g} \mathrm{~kg}^{-1}$ of silt and $74 \mathrm{~g} \mathrm{~kg}^{-1}$ of sand, being classified as a typical Latossolo Vermelho Eutroférrico (Ferralsol, by FAO, 2015) with clay texture (Santos et al., 2013).

The initial data for the physical properties of the soil at the three layers were: $0.0-0.05$ (macroporosity $0.08 \mathrm{~m}^{3}$ $\mathrm{m}^{-3}$, microporosity $0.44 \mathrm{~m}^{3} \mathrm{~m}^{-3}$, total porosity $0.52 \mathrm{~m}^{3} \mathrm{~m}^{-3}$ and bulk density $\left.1.38 \mathrm{Mg} \mathrm{m}^{-3}\right), 0.05-0.10 \mathrm{~m}$ (macroporosity $0.07 \mathrm{~m}^{3} \mathrm{~m}^{-3}$, microporosity $0.45 \mathrm{~m}^{3} \mathrm{~m}^{-3}$, total porosity $0.52 \mathrm{~m}^{3} \mathrm{~m}^{-3}$ and bulk density $1.41 \mathrm{Mg} \mathrm{m}^{-3}$ ) and $0.10-0.15 \mathrm{~m}$ (macroporosity $0.07 \mathrm{~m}^{3} \mathrm{~m}^{-3}$, microporosity $0.45 \mathrm{~m}^{3} \mathrm{~m}^{-3}$, total porosity $0.52 \mathrm{~m}^{3} \mathrm{~m}^{-3}$ and bulk density $\left.1.47 \mathrm{Mg} \mathrm{m}^{-3}\right)$.

\subsection{Experimental Design}

The experimental design used was randomized blocks in a split-plot scheme, with four replications. The main plots consisted of maintenance treatments for the no-tillage system and minimal soil preparation with a chisel. The subplots were composed of treatments of different plant species: wheat, consortium of forage pea + black oat and consortium of black oat + forage turnip, cultivated in winter and both followed by soybeans and lupin.

The experimental area consisted of eight main plots measuring $14 \times 45 \mathrm{~m}$ and three subplots measuring $14 \times 15$ $\mathrm{m}$, totaling 24 plots and an experimental area of $5,040 \mathrm{~m}^{2}$.

\subsection{Conducting the Experiment}

The rainfall data for the months in which the experiment was conducted (April 2016 to October 2017) are shown in Figure 1.

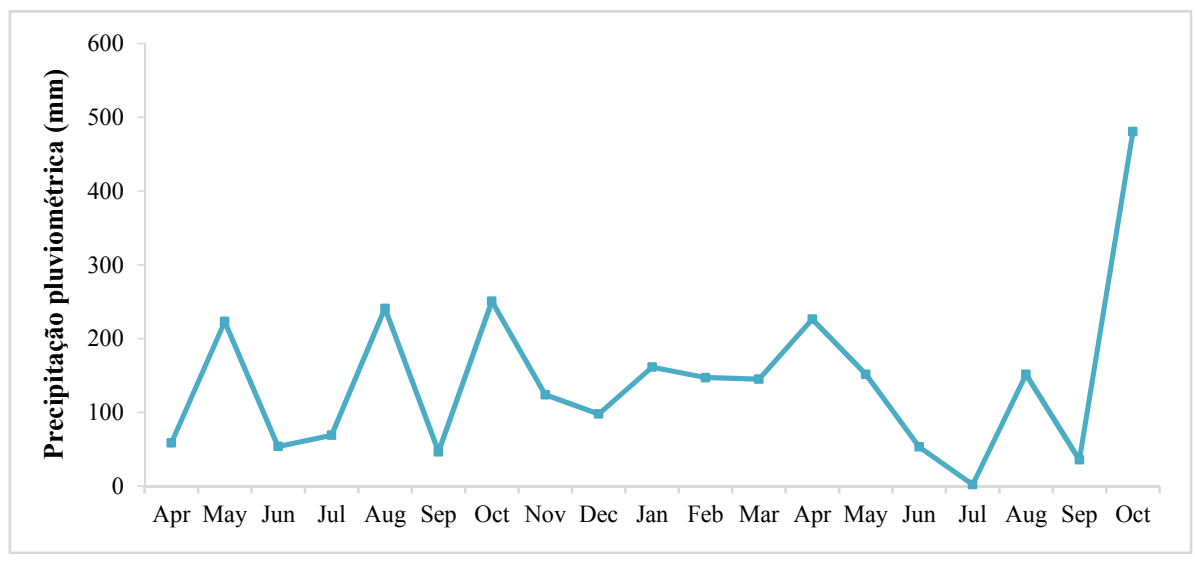

Figure 1. Data of average rainfall for the period from April 2016 to October 2017, in the municipality of Entre Rios do Oeste, Paraná, Brazil

Mechanical scarification was performed in April of 2016 when the soil was in its field capacity $\left(0.22 \mathrm{~g} \mathrm{~kg}^{-1}\right.$ of water). The mechanical chisel subsoiler used was the Piccin model SPDA, containing seven rods with $7.5 \mathrm{~cm}$ thick, spaced at $37.5 \mathrm{~cm}$ and a maximum working depth of $35 \mathrm{~cm}$, equipped with a cutting disc and a cutting roller. For the chisel traction, a John Deere tractor, model $75154 \times 2$ TDA was used. The sowing of cover plants was carried out by a precision seed drill, model Semeato SHM 11/13, with $0.17 \mathrm{~m}$ between lines.

The basic fertilization of cover crops was standardized with a dose of $250 \mathrm{~kg} \mathrm{ha}^{-1}$ of fertilizer 10-15-15 $\left(\mathrm{N}-\mathrm{P}_{2} \mathrm{O}_{5}-\mathrm{K}_{2} \mathrm{O}\right)$ for all treatments. The wheat sowing was carried out with a density of $132 \mathrm{~kg} \mathrm{ha}^{-1}$ of the cultivar CD 150. For the consortium of black oat with forage turnip, the cultivars EMBRAPA 139 and IPR 116 were used, in the sowing densities of 30 and $5 \mathrm{~kg} \mathrm{~h}^{-1}$, respectively. For the consortium of forage pea (cultivar IAPAR 83) with black oat (cultivar EMBRAPA 139), 25 and $30 \mathrm{~kg} \mathrm{ha}^{-1}$ of seeds were used, respectively. 
Phytosanitary treatments were performed as needed and following the technical information manual for wheat and triticale (Cunha \& Caierão, 2014). When the plants reached the flowering stage, chemical desiccation was carried out in a total area with $1,080 \mathrm{~g} \mathrm{ha}^{-1}$ of acid equivalent of glyphosate herbicide, and subsequently there was a need to carry out the mechanical management of the plants, with a brushcutter pulled by a tractor.

After the management of cover crops, soybean cultivar was implanted, cultivar NA 5909 RG, in $0.50 \mathrm{~m}$ spacing. The seeds were inoculated with Bradyrhizobium japonicum and the sowing fertilization with $300 \mathrm{~kg} \mathrm{ha}^{-1}$ of the formulated 02-20-18 (N- $\mathrm{P}_{2} \mathrm{O}_{5}-\mathrm{K}_{2} \mathrm{O}$, respectively) (data not discussed in this experiment). The phytosanitary treatments of the crop were carried out as needed and according to the soy production manual, prepared by the Brazilian Agricultural Research Corporation (Dall'agnol \& Lima, 2011).

After desiccating the area, where the soybean was grown, with glyphosate acid $\left(1,800 \mathrm{~g} \mathrm{ha}^{-1}\right)$, the lupine was sown in April 2017, using the sowing density of $85 \mathrm{~kg} \mathrm{ha}^{-1}$, in leading spacing of $0.35 \mathrm{~m}$. The sowing fertilization was $250 \mathrm{~kg} \mathrm{ha}^{-1}$ of the formulated 02-16-16 (N-P $\mathrm{P}_{2} \mathrm{O}_{5}-\mathrm{K}_{2} \mathrm{O}$, respectively). During the development of the crop, spontaneous plants were controlled by weeding and in the area there was no attack by pests and diseases that required intervention.

The lupine was hasvested manually in September 2017 and in October undisturbed soil samples were collected to evaluate the physical properties of soil, 18 months after the mechanical scarification carried out in April 2016.

\subsection{Evaluation and Statistical Analysis of the Data}

The collections of undisturbed soil samples were performed in volumetric rings of known volume $\left(0.50 \mathrm{~cm}^{3}\right)$, comprising three depths $(0.0-0.5 \mathrm{~m}, 0.5-0.10 \mathrm{~m}$ and $0.10-0.15 \mathrm{~m})$ and at a sample point in each subplot, in order to determine macroporosity, microporosity, total porosity, following the methodology proposed by Almeida, Freitas, Teixeira, Viana, and Donagemma (2017) and soil density, according to the methodology proposed by Almeida, Viana, Teixeira, and Donagemma et al. (2017).

The results of the evaluated attributes were submitted to variance analysis by the SISVAR statistical program (Ferreira, 2014). For cover crops when the analysis was significant, the Tukey test was performed for multiple comparison of means, at $5 \%$ probability.

\section{Results and Discussion}

After 18 months of soil management with a mechanical chisel (April 2016) and maintenance of the no-tillage system, a significant isolated effect $(\mathrm{p}<0.05)$ of these variables was observed for soil density at a depth of $0.10-0.15 \mathrm{~m}$. There was no statistical difference for macroporosity, microporosity, total porosidate at all depths assessed (Table 1).

Table 1. Average values of macroporosity, microporosity, total porosity and soil density at depths of $0.0-0.05$, 0.05-0.10 and 0.10-0.15 $\mathrm{m}$ in area under no-tillage system, with and without mechanical scarification

\begin{tabular}{|c|c|c|c|c|}
\hline Soil management system & Macroporosity & Microporosity & Total porosity & Bulk density \\
\hline & ----- & $m^{3} m^{-3}$ & - & $---\mathrm{Mg} \mathrm{m}^{-3}=-$ \\
\hline \multicolumn{5}{|l|}{$0.00-0.05 \mathrm{~m}$} \\
\hline No-tillage system & $0.08^{\mathrm{ns}}$ & $0.41^{\mathrm{ns}}$ & $0.49^{\text {ns }}$ & $1.37^{\mathrm{ns}}$ \\
\hline Mechanical scarification & 0.09 & 0.40 & 0.49 & 1.38 \\
\hline CV (\%) & 15.64 & 8.17 & 3.52 & 1.99 \\
\hline \multicolumn{5}{|l|}{$0.05-0.10 \mathrm{~m}$} \\
\hline No-tillage system & $0.08^{\mathrm{ns}}$ & $0.39^{\mathrm{ns}}$ & $0.47^{\mathrm{ns}}$ & $1.41^{\mathrm{ns}}$ \\
\hline Mechanical scarification & 0.08 & 0.40 & 0.48 & 1.45 \\
\hline CV (\%) & 7.24 & 3.06 & 2.72 & 2.57 \\
\hline \multicolumn{5}{|l|}{$0.10-0.15 \mathrm{~m}$} \\
\hline No-tillage system & $0.07^{\mathrm{ns}}$ & $0.40^{\mathrm{ns}}$ & $0.47^{\mathrm{ns}}$ & $1.42 \mathrm{~b}$ \\
\hline Mechanical scarification & 0.08 & 0.40 & 0.48 & $1.46 \mathrm{a}$ \\
\hline CV (\%) & 4.40 & 3.23 & 3.18 & 1.29 \\
\hline
\end{tabular}

Note. ${ }^{\text {ns }}$ not significant. Average followed by distinct lowercase letters, vertically, differ statistically from each other using the Tukey test $(\mathrm{p}<0.05)$. 
This can be explained by the fact that scarification makes the soil unstructured and less resistant to loads (Silva \& Rosolem, 2002) and by the wetting and drying processes together with machine traffic, reconsolidation ends up being favored (Reichert, Kaiser, Reinert, \& Riquelme, 2009).

In all soil layers, the macroporosity was below the value considered as critical $\left(0.10 \mathrm{~m}^{3} \cdot \mathrm{m}^{-3}\right)$, which can be considered as limiting water infiltration in soil and an adequate supply of oxygen to the roots (Girardello et al., 2011). Macroporosity below $0.10 \mathrm{~m}^{3} \cdot \mathrm{m}^{-3}$ combined with soil density greater than $1.40 \mathrm{Mg} \cdot \mathrm{m}^{-3}$, as observed in the 0.05-0.10 and 0.10-0.15 m layers, can restrict the root development of crops (Seidel, Mattia, Mattei, \& Corbari, 2015).

At a depth of 0.10-0.15 m, the density differed between the two tillage systems: no-tillage and scarified (Table 1). The no-tillage system contributed to a lower soil density $\left(1.42 \mathrm{Mg} \cdot \mathrm{m}^{-3}\right)$ compared to the soil scarification system $\left(1.46 \mathrm{Mg} \cdot \mathrm{m}^{-3}\right)$. What was also observed by Araujo, Tormena, Inoue, and Costa (2004), in a red dystrophic Latosol, according to which, in areas maintained under a well-managed no-tillage system, the practice has not shown satisfactory results.

These lower values of density in the area maintained without mobilization compared to the area managed with a chisel may be related to the process of soil reconsolidation that occurred in the period of 18 months after the chisel was carried out, since the isolated use of this practice ends up leaving the soil prone to new densification processes. Thus, if the need for its realization is verified, it is important that it be carried out jointly with practices that aim to increase its efficiency in the medium and long term.

However, in both systems these values are above the critical density, and can compromise the balance and physical quality of soil, in addition to that in some cases the productivity of the system can also be compromised.

According to Drescher et al. (2016), the duration of the effects of scarification can be prolonged or delayed, depending on the occurrence or not of factors that control the reconsolidation and resilience of the soil, such as precipitations, wetting and drying cycles, and cultivated species, especially when they occur right after a scarification.

Scarification, when performed eventually, can be used as a practice to reduce the immediate effects of soil compaction and has been shown to be an effective, but short-lived practice (Reichert et al., 2009). What is also corroborated by Drescher et al. (2016), in typical dystrophic red Latosol with clay texture found that the duration of changes caused by mechanical scarification in factors such as density, total porosity and soil macroporosity is less than an agricultural crop.

Silveira Júnior et al. (2012), found limited persistence of the effect of scarification as an attempt to improve the physical quality of an Ferralsol with a clay texture, and after 18 months the soil showed a density similar to that maintained under no-tillage system.

Silva, Silva, Giarola, Tormena, and Sá (2012), evaluating the behavior of soil density and degree of compaction after scarification an Ferralsol cultivated 15 years ago under no-tillage, observed positive effects of scarification only shortly after its completion. Since after 12 months it was not possible to observe the effects of this practice, concluding that the scarification presented a temporary behavior, corroborating with the results of this work.

These results indicate a limited persistence of the management effect with the use of scarifiers as an alternative to unpacking and improving the physical quality of the soil.

This rapid reconsolidation of soil structure, as indicated by the properties of soil density and porosity, according to Drescher et al. (2016), may cause the need for new mechanical uncompacted, which is opposed to the principles of no-tillage system, since the frequent practice of scarification can disrupt aggregates and accelerate the mineralization of organic matter, making the soil more susceptible to new compaction at greater intensity.

The rotation systems significantly changed the soil density at all depths evaluated (Table 2).

It can be observed that in the 0.0-0.05 and 0.10-0.15 m layer in the consortium of black oat and forage turnip, followed by soybean and lupin culture, presented a lower soil density than the areas cultivated with wheat and with consortium of forage pea and black oat, followed by soybeans and lupin.

In the 0.05-0.10 m layer, the consortium of black oat and forage turnip showed statistical difference only in relation to single wheat cultivation.

The probable justification is that the forage turnip plants have an aggressive pivoting root system, capable of breaking the compacted soil layers. The black oat are characterized by presenting a vast fasciculate root system that develops, for the most part, in the upper layers, forming channels in soil and contributing to the improvement of soil structure, which helps to reduce compaction. 
Table 2. Average values of macroporosity, microporosity, total porosity and soil density at depths of $0.0-0.05$, 0.05-0.10 and 0.10-0.15 $\mathrm{m}$ after different crop rotation systems

\begin{tabular}{|c|c|c|c|c|}
\hline Succession & Macroporosity & Microporosity & Total Porosity & Soil density \\
\hline & 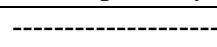 & $\mathrm{m}^{3} \mathrm{~m}^{-3}$ & ---------------------- & $---\mathrm{Mg} \mathrm{m}^{-3}-\cdots$ \\
\hline \multicolumn{5}{|l|}{$0.0-0.05 \mathrm{~m}$} \\
\hline Wheat/Soybean/Lupin & $0.08^{\mathrm{ns}}$ & $0.40^{\mathrm{ns}}$ & $0.50^{\mathrm{ns}}$ & $1.43 \mathrm{a}$ \\
\hline Oat+Turnip/Soybean/Lupin & 0.09 & 0.41 & 0.50 & $1.32 \mathrm{c}$ \\
\hline Pea+Oat/Soybean/Lupin & 0.09 & 0.41 & 0.51 & $1.37 \mathrm{~b}$ \\
\hline CV $(\%)$ & 11.16 & 4.45 & 5.21 & 1.63 \\
\hline \multicolumn{5}{|l|}{$0.05-0.10 \mathrm{~m}$} \\
\hline Wheat/Soybean/Lupin & $0.08^{\mathrm{ns}}$ & $0.39^{\mathrm{ns}}$ & $0.49^{\text {ns }}$ & $1.47 \mathrm{a}$ \\
\hline Oat+Turnip/Soybean/Lupin & 0.09 & 0.40 & 0.50 & $1.40 \mathrm{~b}$ \\
\hline Pea+Oat/Soybean/Lupin & 0.08 & 0.40 & 0.50 & $1.43 \mathrm{~b}$ \\
\hline CV $(\%)$ & 10.29 & 3.40 & 3.89 & 1.65 \\
\hline \multicolumn{5}{|l|}{$0.10-0.15 \mathrm{~m}$} \\
\hline Wheat/Soybean/Lupin & $0.08^{\mathrm{ns}}$ & $0.41^{\mathrm{ns}}$ & $0.47^{\mathrm{ns}}$ & $1.51 \mathrm{a}$ \\
\hline Oat+Turnip/Soybean/Lupin & 0.08 & 0.40 & 0.48 & $1.38 \mathrm{c}$ \\
\hline Pea+Oat/Soybean/Lupin & 0.07 & 0.40 & 0.48 & $1.43 \mathrm{~b}$ \\
\hline $\mathrm{CV}(\%)$ & 11.51 & 4.38 & 4.25 & 2.05 \\
\hline
\end{tabular}

Note. ${ }^{\text {ns }}$ not significant. Average followed by distinct lowercase letters, vertically, differ statistically from each other using the Tukey test $(\mathrm{p}<0.05)$.

In addition, the succession with soybeans and lupin, which have pivoting root systems, also influences this physical property of soil, contributing to the maintenance of physical quality.

It is possible to observe that the intercropped use of plants that contain root systems with different morphologies and development is an important practice to recover and maintain the physical quality of soil, as it explores a larger soil volume.

In addition, with the decomposition of remaining cultural remains, there is an increase in organic matter in soil, which, according to Braida, Reichert, Reinert, and Sequinatto (2008), provides elasticity to it, reducing the susceptibility to compaction process.

The areas cultivated with wheat were compacted, since the soil density in these areas was above $1.40 \mathrm{Mg} \mathrm{m}^{-3}$ (Seidel et al., 2015), indicating that although the plant has a vast fasciculate root system that is characterized by develops more homogeneously, it did not have a long-lasting uncompacted effect.

In a study by Valicheski, Grossklaus, Stürmer, Tramontin, and Baade (2012), seeking to evaluate the effect of compaction on the physical attributes of soil and to identify which species of green manure has the greatest potential to mitigate the effects of soil compaction, found that the cultivation of oat and forage turnip was efficient in minimizing the effects soil compaction caused by traffic.

Cardoso, Bento, Moreski, and Gasparotto (2014), seeking to evaluate the effects of green cover on the physical-biological properties of soil, found that the plants provided an increase in the content of organic matter and a reduction in the density of soil.

\section{Conclusions}

After 18 months, the scarified soil showed higher density (0.10-015 m layer) when compared to the no-tillage system. Demonstrating that this isolated decompression alternative does not improve the physical properties of soil.

The area in succession to oat + turnip/soybean/lupin showed lower soil density.

\section{Acknowledgements}

The authors would like to thank the State University of Western Paraná for their support in the development of the research.

\section{References}

Almeida, B. G. de, Freitas, P. L. de, Teixeira, W. G., Viana, J. H. M., \& Donagemma, G. K. (2017). Porosidade. In P. C. Teixeira, G. K. Donagemma, A. Fontana, \& W. G. Teixeira (Eds.), Manual de métodos de análise de solo (pp. 2-94). Brasília, Embrapa. 
Almeida, B. G. de, Viana, J. H. M., Teixeira, W. G., \& Donagemma, G. K. (2017). Densidade do solo. In P. C. Teixeira, G. K. Donagemma, A. Fontana, \& W. G. Teixeira (Eds.), Manual de métodos de análise de solo (pp. 65-75). Brasília, Embrapa.

Araujo, M. A., Tormena, C. A., Inoue, T. T., \& Costa, A. C. S. (2004). Efeitos da escarificação na qualidade física de um Latossolo vermelho distroférrico após treze anos de semeadura direta. Revista Brasileira de Ciência do Solo, 28(3), 495-504. https://doi.org/10.1590/S0100-06832004000300011

Bortolini, C. G., Silva, P. R. F., \& Argenta, G. (2000). Efeito de resíduos de plantas jovens de aveia preta em cobertura de solo no crescimento inicial do milho. Pesquisa Agropecuária Gaúcha, 6(1), 83-88.

Braida, J. A., Reichert, J. M., Reinert, D. J., \& Sequinatto, L. (2008). Elasticidade do solo em função da umidade e do teor de carbono orgânico. Revista Brasileira de Ciência do Solo, 32(2), 477-485. https://doi.org/ 10.1590/S0100-06832008000200002

Calegari, A. (2001). Rotação de culturas e plantas de cobertura como sustentáculo do sistema de plantio direto (p. 241). Congresso Brasileiro de Ciência do Solo, Londrina. Anais... Londrina, Sociedade Brasileira de Ciência do Solo.

Cardoso, R. A., Bento, A. S., Moreski, H. M., \& Gasparotto, F. (2014). Influência da adubação verde nas propriedades físicas e biológicas do solo e na produtividade da cultura de soja. Semina: Ciências Biológicas e da Saúde, 35(2), 51-60. https://doi.org/10.5433/1679-0367.2014v35n2p51

Caviglione, J. H., Kiihl, L. R. B., Caramori, P. H., \& Oliveira, D. (2000). Cartas climáticas do Paraná. Londrina: IAPAR.

Cremonez, P. A., Feroldi, M., Feiden, A., Rossi, E. de, Nadaleti, W. C., \& Antonelli, J. (2013). Tremoço: manejo e aplicações. Acta Iguazu, 2, 98-108.

Cubilla, M., Reinert, D. J., Aita, C., \& Reichert, J. M. (2002). Plantas de cobertura do solo: uma alternativa para aliviar a compactação em sistema plantio direto. Revista Plantio Direto, 71, 29-32.

Cunha, G. R. da, \& Caierão, E. (2015). Informações Técnicas Para Trigo e Triticale-Safra 2015 (p. 229). VIII Reunião da Comissão Brasileira de Pesquisa de Trigo e Triticale.

Dall'agnol, V. F., \& Lima, A. B. A. (2011). Tecnologias de produção de soja-Região central do Brasil 2012 e 2013 (Sistema de Produção, No. 15). Londrina: Embrapa Soja.

Donagemma, G. K., Viana, J. H. M., Almeida, B. G. de, Ruiz, H. A., Klein, V. A., Dechen, S. C. F., \& Fernandes, R. B. A. (2017). Análise granulométrica. In P. C. Teixeira, G. K. Donagemma, A. Fontana, \& W. G. Teixeira (Eds.), Manual de métodos de análise de solo (pp. 95-116). Brasília: Embrapa.

Doneda, A., Aita, C., Giacomini, S. J., Miola, E. C. C., Giacomini, D. A., Schirmann, J., \& Gonzatto, R. (2012). Fitomassa e decomposição de resíduos de plantas de cobertura puras e consorciadas. Revista Brasileira de Ciência do Solo, 36(6), 1714-1723. https://doi.org/10.1590/S0100-06832012000600005

Drescher, M. S., Eltz, F. L. F., Denardin, J. E., \& Faganello, A. (2011). Persistência do efeito de intervenções mecânicas para a descompactação de solos sob plantio direto. Revista Brasileira de Ciência do Solo, 35(5), 1713-1722. https://doi.org/10.1590/S0100-06832011000500026

Drescher, M. S., Reinert, D. J., Denardin, J. E., Gubiani, P. I., Faganello, A., \& Drescher, G. L. (2016). Duração das alterações em propriedades físico-hídricas de Latossolo argiloso decorrentes da escarificação mecânica. Pesquisa Agropecuária Brasileira, 51(2), 159-168. https://doi.org/10.1590/S0100-204X2016000200008

FAO (Food and Agriculture Organization of the United Nations). (2014). World Reference Base for Soil Resourses: Update 2015 International Soil Classification System for Naming Soils and Creating Legends for Soil Maps. Rome: FAO. Retrieved June 16, 2020, from http://www.fao.org/3/a-i3794en.pdf

Farias, A. R., Dossa, A. A., Mingoti, R., Acosta, A, S., Cunha, G. R. da, \& Spadotto, C. A. (2017). Dinâmica especial da cultura do trigo no Brasil no período de 1990 a 2014 (p. 28). São Paulo, Embrapa Gestão Territorial.

Ferreira, D. F. (2014). Sisvar: A guide for its bootstrap procedures in multiple comparisons. Ciência $e$ Agrotecnologia, 38(2), 109-112. https://doi.org/10.1590/S1413-70542014000200001

Girardello, V. C., Amado, T. J. C., Nicoloso, R. S., Hörbe, T. A. N., Ferreira, A. O., Tabaldi, F. M., \& Lanzanova, M. E. (2011). Alterações nos atributos físicos de um latossolo vermelho sob plantio direto induzidas por 
diferentes tipos de escarificadores e o rendimento da soja. Revista Brasileira de Ciência do Solo, 35(6), 2115-2126. https://doi.org/10.1590/S0100-06832011000600026

Girardello, V. C., Amado, T. J. C., Santi, A. L., Cherubin, M. R., Kunz, J., \& Teixeira, T. G. (2014). Resistência à penetração, eficiência de de escarificadores mecânicos e produtividade da soja em Latossolo argiloso manejado sob plantio direto de longa duração. Revista Brasileira de Ciência do Solo, 38(4), 1234-1244. https://doi.org/10.1590/S0100-06832014000400020

Hernani, L. C., Endres, V. C., Pitol, C., \& Salton, J. C. (1995). Adubos verdes de outono/inverno no Mato Grosso do Sul (pp. 55-60). Dourados, Centro de Pesquisa Agropecuária do Oeste.

Klein, V. A. (2010). Compactação do solo, um grave problema na agricultura brasileira, que precisa ser enfrentado com seriedade. Revista Plantar, 42, 38-40.

Panachuki, E., Bertol, I., Alves Sobrinho, T., Oliveira, P. T. S. de, \& Rodrigues, D. B. B. (2011). Perdas de solo e de água e infiltração de água em Latossolo Vermelho sob sistemas de manejo. Revista Brasileira de Ciência do Solo, 35(5), 1777-1785. https://doi.org/10.1590/S0100-06832011000500032

Reichert, J. M., Kaiser, D. R., Reinert, D. J., \& Riquelme, U. F. B. (2009). Variação temporal de propriedades físicas do solo e crescimento radicular de feijoeiro em quatro sistemas de manejo. Pesquisa Agropecuária Brasileira, 44(3), 310-319. https://doi.org/10.1590/S0100-204X2009000300013

Rosa, H. A., Secco, D., Santos, R. F., Marins, A. C. de, Fornasari, C. H., \& Veloso, G. (2018). Structuring potential of cover crops in a clayey oxisol and their effect on crambe grain yield and oil contente. Revista Scientia Agraria, 19(1), 160-167. https://doi.org/10.5380/rsa.v19i1.51266

Santos, H. G. dos, Jacomine, P. K. T., Anjos, L. H. C. dos, Oliveira, V. A. de, Lumbreras, J. F., Coelho, M. R., ... Oliveira, J. B. de. (2013). Sistema Brasileiro de Classificação de Solos. Brasília: Embrapa.

Seidel, E. P., Mattia, V., Mattei, E., \& Corbari, F. (2015). Produção de matéria seca e propriedades físicas do solo na consorciação milho e braquiária. Scientia Agraria Paranaensis, 14(1), 18-24. https://doi.org/ 10.18188/sap.v14i1.8226

Silva, R. H. da, \& Rosolem, C. A. (2002). Crescimento radicular de soja em razão da sucessão de cultivos e da compactação do solo. Pesquisa Agropecuária Brasileira, 37(6), 855-860. https://doi.org/10.1590/S0100-20 4X2002000600015

Silva, S. G. C., Silva, A. P. da, Giarola, N. F. B., Tormena, C. A., \& Sá, J. C. M. (2012). Temporary effect of chiseling on the compaction of a Rhodic Hapludox under no-tillage. Revista Brasileira de Ciência do Solo, 36(2), 547-555. https://doi.org/10.1590/S0100-0683201200020002

Silveira Junior, S. D. da, Silva, A. P. da, Figueiredo, G. C., Tormena, C. A., \& Giarola, N. F. B. (2012). Qualidade física de um Latossolo vermelho sob plantio direto submetido à descompactação mecânica $\mathrm{e}$ biológica. Revista Brasileira de Ciência do Solo, 36(6), 1854-1867. https://doi.org/10.1590/S0100-06832 012000600020

Valicheski, R. R., Grossklaus, F., Stürmer, S. L. K., Tramontin, A. L., \& Baade, E. S. A. S. (2012). Desenvolvimento de plantas de cobertura e produtividade da soja conforme atributos físicos em solo compactado. Revista Brasileira de Engenharia Agrícola e Ambiental, 16(9), 969-977. https://doi.org/ $10.1590 / \mathrm{S} 1415-43662012000900007$

\section{Copyrights}

Copyright for this article is retained by the author(s), with first publication rights granted to the journal.

This is an open-access article distributed under the terms and conditions of the Creative Commons Attribution license (http://creativecommons.org/licenses/by/4.0/). 